\section{Nyttig, men litt kjedelig}

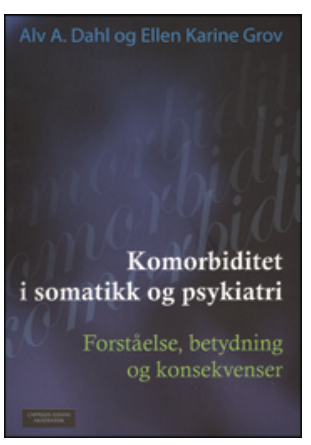

Alv A. Dahl, Ellen Karine Grov Komorbiditet i somatikk og psykiatri Forståelse, betydning og konsekvenser. 156 s, tab, ill. Oslo: Cappelen Damm Akademisk, 2014. Pris NOK 248 ISBN 978-82-02-42465-7

Forfatterne skal ha honnør for at de har gått løs på den utfordringen det er å skulle gi en samlet fremstilling av komorbiditet og konsekvenser for diagnostikk, behandling og forløp. I møte med pasienter, både i kommunehelsetjeneste og spesialisthelsetjeneste, er kompleksitet og sammensatte symptom-og sykdomsbilder vanlig. Helsepersonell må hele tiden forholde seg til komorbiditet. Ikke minst gjelder dette i møte med eldre pasienter, komorbiditetens kjernetropper, som forfatterne omtaler dem som. Man kan derfor undre seg over, slik forfatterne gjør i bokens forord, hvorfor det ikke finnes mer litteratur om komorbiditet. Boken ønskes derfor velkommen.

Boken henvender seg først og fremst til medisinstudenter og masterstudenter i sykepleie og andre helsefag, samt leger i primærog spesialisthelsetjeneste. Etter min mening vil den også kunne være nyttig for helsepersonell generelt innenfor somatikk og psykiatri, men også i rushelsetjeneste og habilitering. Boken gir en oversiktlig fremstilling av komorbiditet og tilstøtende begreper og har totalt 11 kapitler. Forfatterne tar for seg og redegjør for tre hovedområder; komorbiditet mellom sentrale somatiske sykdommer, psykiske lidelser og komorbiditet og komorbiditet mellom sentrale psykiske lidelser og somatiske sykdommer. Det legges vekt på grundig kartlegging og bruk av standardiserte kartleggingsverktøy for vurdering av komorbiditet. Forfatterne oppgir dessuten referanser til ulike nettsteder hvor man kan laste ned kartleggingsverktøy, noe av det som er mest nyttig med boken. Videre bidrar også referanseliste til hvert kapittel til at boken er oversiktlig.

I kapitlene benyttes tabeller og figurer for å illustrere viktig poeng. Innledningsvis presenteres også et pasientkasus for å tydeliggjøre budskapet. Dessverre følges ikke kasuistikken opp videre og i de fleste kapitlene er det derfor ingen referanse til konkrete kliniske eksempler. Det er synd, for flere kasuistikker ville gjort stoffet mer levende og gjenkjennbart for leseren. Totalinntrykket blir derved at boken fremstår noe oppramsende og derved litt kjedelig. Til tross for disse manglene er det likevel all grunn til å anbefale boken.

\section{Lærebok om miljø- og arbeidsmedisin i ny utgave}

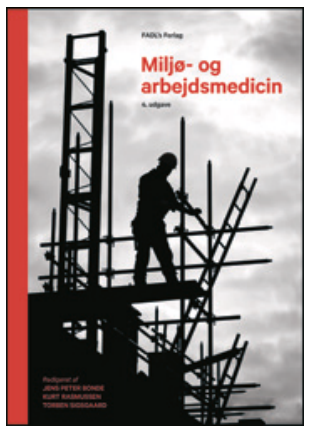

Jens Petter Bonde, Knut Rasmussen,

Torben Sigsgaard, red.

Miljø- og arbejdsmedicin

4. utg. 354 s, tab, ill. København: FADL's

Forlag, 2015. Pris DKK 500

ISBN 978-87-7749-715-5

I sin fjerde utgave er dette fortsatt en lærebok som jeg anbefaler. Utgaven har de samme redaktørene som tidligere, og bygger på de foregående utgavene, men den har noen nye kapitler og forfattere. Boken er inndelt i 23 kapitler som til sammen dekker de mest sentrale emnene innenfor disse to samfunnsmedisinske spesialområdene.

De innledende kapitlene omhandler risikovurdering, forebygging og toksikologi og følges av kapitler om vann og mat, spillvann og avfall, luftforurensning, inneklima, stråling, ulykker og livsstil, før boken avsluttes med 12 kapitler om sentrale arbeidsmedisinske temaer som lunge- og hudsykdommer, lidelser i bevegelsesapparatet, stress og psykiske lidelser, kreft, fruktbarhet og svangerskap, støy, smittsomme sykdommer og et kapittel om det de kaller funksjonelle miljøsyndromer (el-allergi, musearm, aerotoksisk syndrom mv.) I sluttkapitlet om andre arbeidsbetingede sykdommer er det en kort omtale av sykdommer i nervesystem, hjerte, lever, nyrer og tenner. Teksten tar utgangspunkt i danske forhold, men det aller meste kan gjelde for norske forhold også.

Kapitlene har gjennomgående høy faglig kvalitet. En eller flere av redaktørene er med på i alt 17 av kapitlene, noe som kan forklare at det er lite overlapping mellom kapitlene. Tidligere utgaver var etter min mening noe skjemmet av anglisismer, men de er nå borte. Borte er også den, i denne sammenheng, unødvendige generelle medisinske kunnskapen som det var mye av, særlig i den første utgaven.

Hvert kapittel er utstyrt med en eller flere praktiske kasuistikker som gir teksten liv og som illustrer teorien godt. Kapitlene avsluttes med kontrollspørsmål som leseren kan bryne seg på, og har også med en litteraturliste og noen nettadresser.

Boken er myntet på medisinstudenter og leger og angis å dekke pensum på studiet $\mathrm{i}$ Odense, Aarhus og København. Den skulle være fyllestgjørende også for norske forhold, og både studenter og leger, kanskje særlig kommuneleger, allmennleger, bedriftsleger og leger i spesialisering i arbeidsmedisin, vil ha glede av den. Noe tilsvarende verk finnes ikke på norsk.

Håkon Lasse Leira

Pensjonert lege, Trondheim 